\title{
Education financing and student achievement
}

\section{Giuseppe Bertola and Daniele Checchi}

It is widely urged that the great need in schooling is more money to build more facilities and to pay higher salaries to teachers in order to attract better teachers. This seems a false diagnosis. ... The problem is not primarily that we are spending too little money - though we may be - but that we are getting so little per dollar spent. (Friedman, 1995, p. 96).

We briefly review how schools financial resources affect the amount, quality, and heterogeneity of education, and how in turn the provision of educational services bears on students' achievement. Then, we discuss the implications of different ways of linking school resources to student achievement, focusing in particular on the distinction between family-based and State-based channels of financial support.

\section{Introduction}

Economists believe that giving appropriate incentives to the relevant agents is key to ensuring efficiency of their interactions' outcomes: hence, the argument in favour of explicitly linking financial incentives to observable schooling outcomes can be very brief. Following Friedman, (1995), economists often advocate voucher systems whereby families may reward better schools with more financial resources, or at least systems of school financing where bureaucratic assessment programs (rather than families) channel more resources to better-performing schools and teachers.

From this perspective, it may be puzzling to see that performance-related pay is not standard in educational systems. In this paper, we review the possible pitfalls facing reliance on financial incentives in the education field. Economists, of course, are also aware that interactions can be imperfect when resources and results (the input and output of education) are imperfectly observable, and that improving incentives in specific dimensions need not improve the system's overall efficiency when other interactions are left unaddressed and externalities play 
an important role. Our discussion below is organized along two dimensions. First, we note that education has both private and public returns, and externalities cannot be ruled out. Hence, the implications of financial allocations based on the same hypothetically perfect measures of student achievement would in general differ when families rather than the State bear the cost of education financing. Second, we discuss the extent to which the outcomes ultimately relevant to either families or government agencies may in fact be observable.

From this perspective, we review the benefits and possible pitfalls of enhanced financial responsibility arising from families' ability to determine schools' resources - either through participation in a private education market, or through mobility across locally financed school districts, or through allocation of State-financed vouchers or enrolment-based State transfers. Families need not base their choices on efficient measures of school output when parents do not have access to the relevant information, and parental choice need not result in efficient social outcomes when the parents' objectives fail to internalise relevant externalities.

Then, we review possible pitfalls in State-organized incentives: while the State could in principle internalise all relevant interactions, bureaucratic decisions need not be based on relevant indicators, and may be distorted by the role of teachers in influencing the choice and measurement of indicators. For both families and government agencies, relying on achievement indicators may be more difficult and less reliable than relying on simple input and process indicators.

We conclude that enhanced emphasis on financial responsibility by school providers may, but need not improve a schooling system's performance. Our brief review of the relevant theoretical mechanisms indicates that the pros and cons of different financing methods are likely to differ across types and levels of schooling: family-based channelling of resources is more likely to result in appropriate incentives when returns to education are predominantly private. Theory and evidence also suggest that accurate and reliable measures of school performance should play an essential role in any financial incentive scheme, and that availability of adequate performance measures is in practice very scarce.

\section{Production of education}

An individual's educational outcome can be measured in terms of educational variables (years of schooling achieved; marks obtained at each level; literacy/numeracy scores; probability of transition to further education), or in terms of labour market variables (earnings; access to further training; better job quality). Educational variables determine the individual's human capital, which depends in general on the quantity and quality of knowledge achieved.

The inputs to the educational process whose output is human capital include economic (and financial) resources. A vast literature has studied whether school 
resources are effective in raising educational outputs. ${ }^{1}$ For our discussion, we will suppose that additional resources are useful and effective (their marginal productivity is positive) and focus on the efficiency of their allocation and use. Production of individual human capital, in fact, also depends on key organizational aspects, such as class and establishment size. And it also depends on the characteristics (talent, and family background) not only of the individual concerned, but also of his classmates: Benabou (1996) and many other contributions emphasize that the extent of school stratification (whether students of similar background and talent are schooled together) has important implications for educational outcomes. In theory, school managers can vary not only class size, but also the quality of students in that schools can sort students according to their observable abilities, as in the admission to some private schools and/or to most high schools. Hence, suppliers of education can offer different possibilities of human capital formation in each class. Since families choose schools according to their expectations with respect to admission and class formation policies, actual human capital formation comes out as the equilibrium result of supply and demand for school quality. In what follows we focus on organisational issues, disregarding issues of unobservable characteristics of individuals as well as issues of resource effectiveness.

At the level of the whole school system, school organization can be read along three dimensions: comprehensive vs. stratified schools, public vs. private, centrally financed vs. locally financed. The distinction between comprehensive and stratified educational systems typically emerges at the stage of secondary school: the former system offers to all students the same type of educational track, typically based on general competences; typical examples are the English and the North American school systems. The latter system sorts students according to their intended labour market position, since students (and more frequently their families) can choose among vocational training or academic-oriented preparation; the German system is an archetype of this organisation. While the first dimension concerns the possibility of market segmentation (in a generalist school system all customers obtain the same commodity, whereas in a stratified system customers can choose across different goods), the second one has to do with the amount of resources available. In a public system financed through general taxation all students receive an identical treatment (i.e. different students obtain the same amount of resources when they enrol in the same type of school), whereas in a private system families can choose the preferred amount of resources invested in the education of offspring. As a consequence, the amount of resources available to students depends on family wealth (i.e. identical students from different families obtain different amount of resources). The third divide partially overlaps with the second, as long as there are local differences in people preferences and families are territorially mobile. In a decentralised system schools characterised by high and low levels of spending on students may coexist. If families are sufficiently mobile, they will "vote with their feet», i.e. they will (optimally) 
choose their residence by maximising the adherence to their preferred spending (Tiebout, 1956). In addition, local financing of schools, coupled with territorial mobility, increases school competition for attracting more and better students.

These three dimensions can be combined in alternative ways, also depending on the schooling levels. A stratified, mainly public and centrally financed educational system (as in Italy) and a generalist, mixed public-private and locally financed educational system (as in the United States) are both possible. Empirically, it is straightforward to obtain information on the source of financing, but the other aspects are harder to measure. The following tables provide some aggregate evidence on the fact that private source of funding rises with pre-compulsory and post-compulsory education: in the first case, it pays for either insufficient public provision (and/or possible amenities like extended timetables, improved facilities, and so on); in the second case, private return on education favours the partial transfer of costs onto the final earners of educational benefits.

\section{Table 1: Proportion of public and private expenditure on educational institutions (1999)}

\begin{tabular}{|l|c|c|c|c|c|c|}
\hline & \multicolumn{2}{|c|}{ pre-primary } & primary and secondary & \multicolumn{2}{c|}{ tertiary education } \\
\hline & public & private & public & private & public & private \\
\hline France & 95.8 & 4.2 & 92.8 & 7.2 & 84.3 & 15.7 \\
\hline Germany & 62.2 & 37.8 & 75.6 & 24.4 & 91.5 & 8.5 \\
\hline Italy & 98.7 & 1.3 & 98.3 & 1.7 & 80.3 & 19.7 \\
\hline Japan & 48.6 & 51.4 & 91.8 & 8.2 & 44.5 & 55.5 \\
\hline Switzerland & 99.9 & 0.1 & 87.7 & 12.3 & 96.7 & 3.3 \\
\hline United Kingdom & 95.6 & 4.4 & 88.2 & 11.8 & 63.2 & 36.8 \\
\hline United States & 90.3 & 9.7 & 90.7 & 9.3 & 46.9 & 53.1 \\
\hline OECD average & 82.2 & 17.8 & 92.1 & 7.9 & 79.2 & 20.8 \\
\hline
\end{tabular}

Source: OECD 2003, Education at a glance, Paris, table B4.2

An indirect measure of the degree of homogeneity of education provision can be obtained by examining the dispersion of students' achievements in terms of literacy and numeracy. Table 2 reproduces the decomposition of variation of student performance as recorder by the PISA assessment conducted in 2000 under the supervision of OECD. Many factors contribute to the variation in average student performance within each country: subnational differences due to different jurisdictions, range of the private sector, presence of differentiated curricula in accordance with past performance, socio-economic intake. The more centralised is a schooling system, the lower will be the overall dispersion in student tests; the less stratified and/or the lower the degree of differentiation (due to either local financing or access to private education), the lower will be the between-school variation. From this table we observe the emergence of potential trade-off: stratified educational systems yield the highest between-school varia- 
tion (Italy and Germany) ${ }^{2}$, but this contributes less to overall dispersion whenever the country is centrally financed (Italy, but not Germany). On the other extreme, the more comprehensive is the system, the greater will be the performance variation within each school, whereas the overall dispersion depends on the source and the amount of funding.

Table 2: Variance decomposition in literacy ability (PISA 2000)

\begin{tabular}{|l|c|c|c|c|c|}
\hline & $\begin{array}{c}\text { Overall } \\
\text { variation } \\
\text { (mean=500) }\end{array}$ & $\begin{array}{c}\text { between- } \\
\text { school } \\
\text { variation (\%) }\end{array}$ & $\begin{array}{c}\text { within- } \\
\text { school } \\
\text { variation (\%) }\end{array}$ & $\begin{array}{c}\text { secondary } \\
\text { school } \\
\text { system }\end{array}$ & $\begin{array}{c}\text { private sector } \\
\text { in secondary } \\
\text { school }\end{array}$ \\
\hline Germany & 12.368 & 56.11 & 43.89 & stratified & high \\
\hline Italy & 8.356 & 56.49 & 43.51 & stratified & low \\
\hline Japan & 7.358 & 46.03 & 53.97 & stratified & intermediate \\
\hline Switzerland & 10.408 & 43.40 & 56.60 & stratified & intermediate \\
\hline United Kingdom & 10.098 & 20.57 & 79.43 & comprehensive & intermediate \\
\hline United States & 10.979 & 44.69 & 55.31 & comprehensive & intermediate \\
\hline
\end{tabular}

Source: first three columns: OECD 2003, Education at a glance, Paris, table A7.1; fourth column: OECD 1996, Education at a glance - OECD Indicators, Paris (country profiles); fifth column: see table 1.

Note: the first column reports the variance of reading ability scores in the whole sample; the second column reports the fractions of that variance reflecting different average scores across schools, and the third reports the variance component due to variability around those average scores in each school.

These three dimensions (degree of curricula stratification, private share in education provision, local financing) overlap with each other and are interrelated, in that all contribute to segmentation of the «market for education». Standard economic theory suggests three points as regards product differentiation:

i) horizontal differentiation (products cannot be ranked in terms of quality, but are different from the customers' point of view) and vertical differentiation (products of higher quality are more costly to produce) have different implications;

ii) a higher degree of differentiation and segmentation increases the market power of firms, since each of them is confronted with a stable pool of customers.

iii) in a segmented market, customers are more satisfied (since each customer gets closer to his preferred bundle of consumption), but consumption inequality increases.

As regards education, the first point highlights the central issue of information available to families. Do parents know the quality of available schools? When 
confronting the choice between private or public education, do they take into account quality considerations, and how and where do they get access to this information? Market-power considerations are not very relevant when the private supply of educational services is modest, but can have important pricing implications when the private sector has a large market share, as in the case of US university education. ${ }^{3}$ Finally, inequality considerations are relevant from a social point of view: if uniformity of education generates positive externalities, segmentation can be socially suboptimal.

\section{The social role of education}

Above, we discussed how combinations of economic and human resources determine the production of human capital, and how the design of the educational system may provide different degrees of segmentation. When turning to a discussion of the character of such combinations in reality, and of the efficiency of the resulting outcomes, it is important to recognize that a given pupil's education has effects in a variety of dimensions. Educational achievements bear on the pupil's own labour market success, but do not do so in complete isolation, and important spillovers are theoretically and empirically relevant. On the one hand, the pupil's educational achievement can bear on his or her future income through its relative (to other market participants) characteristics, rather than on an absolute basis. On the other hand, the average education of the population can impact social production in much more complex ways than one might expect by just averaging individual outcomes: one individual's education can have positive spillovers on others' productivity through non-market interactions. Further, a degree of uniformity of educational experiences can be beneficial if it fosters easier social and economic interactions (for example, because all citizens share a language and other modes of communication), and of course society can also value equality per se. From this perspective, education plays three related but conceptually distinct socio-economic roles. ${ }^{4}$

First of all, the school system provides young individuals with essential communication and behavioural skills that will allow them to interact with other members of society. In primary school, children learn not only how to read and write, but also to respect each other and obey rules. Such communication and behavioural skills are essential for the smooth functioning of any organised system of social interaction. 5

A second very important role of education is of course that of supplying the labour market with suitably trained and selected factors of production. Schools embody in new generations advanced productive skills (buman capital), in the form of an ability to formulate correctly, analyse, and solve problems, and/or of technical know-how. The former skills are general, and can be learned by exercising and refining one's ability to reason at an abstract level; the latter skills can 
be learned more mechanically, for specific applications. School systems also select (screen) members of new generations, and sort them according to their ability to perform different tasks. The educational curriculum of a student has value in the labour market if it enhances and certifies general and/or specific skills and talents. Hence, not only society but also individual students benefits (in the form of higher wages and/or better employment opportunities) from school curricula that transmit and certify their usefulness in production.

In order to interpret many features of school systems in market economies, however, it is important to account for their third important role, namely that of preserving (or not) the structure of social stratification across generations. The private value of education is obviously higher when high-quality curricula are scarce in the labour market and, more generally, in the socio-economic system. When supplying and certifying skills and talents, schools sort members of new generations according to their socio-economic duties in society, and the structure of a schooling system can prevent or foster intergenerational mobility across different ladders of the social structure.

\section{Efficiency conditions}

Economic efficiency is easily defined as a situation where the costs and benefits are equated on every relevant margin, taking nondivisibilities and increasing returns into account when necessary. Since the production and benefits of education both involve many complex and interrelated considerations across individual decision makers, it not straightforward for either centralized or decentralized allocation mechanisms to achieve such efficiency. Some of the relevant "production factors" (talent, background) are endowed to educational establishments involuntarily by the students themselves, rather than through market transactions, and some of the benefits of education are public in nature, i.e., they accrue to society at large rather than to specific individuals.

Take for example the problem of class formation. From an efficiency point of view, at least three issues arise when trying to define optimal class formation: selection of students according to their ability, class composition (i.e. mixing students of different ability in the same class or creating ability-homogenous classes), and class size. The first two issues arise whenever students are differently endowed with abilities that are relevant in educational achievement (attentiveness, brightness, cooperation, but also more favourable family background). Otherwise, only the third one remains relevant. The problem of screening students arises from the unobservable nature of individual ability. A large part of schooling activity is devoted to testing students in order to obtain indirect measures of these unobservables. Test scores are in turn used as screening devices for admission to further education. On the whole, one could state that one by-product of schooling activity is information about students' quality. ${ }^{6}$ This view sup- 
ports the idea of educational certificates as signals for prospective employers: the longer a student remains in school, the more extensive selection has been passed, the greater must be her unobservable ability. While testing is the only alternative in the case of imperfect symmetric information (neither the student, her family or the teachers know her ability in advance), whenever students and families have an informational advantage on unobservable ability, admission fees can be an alternative device to screening students. Suppose one intends to create an élite school by admitting only the best students, in a context where families have superior information about students' abilities (imperfect asymmetric information). All families would like to gain access to the exclusive élite school, because this will grant higher returns to education in the future, thanks to the better human capital formation. There are two alternative ways of sorting out the best students: either through submitting all applicants to specific exams, or by selecting them in accordance with their willingness to pay. The main drawback of the allocation mechanism based on testing is that it wastes resources: students spend time to prepare for the admission tests, families spend money in order to provide extra tutoring for the same aim, schools have to pay teachers (or external examining agencies) to mark exams. In addition, student performance is very often correlated to family background, and therefore the final result does not always identify "pure» ability in the students. ${ }^{7}$ The market mechanism (selecting students by means of admission fees, increasing with perceived school quality) is in principle more efficient: by ordering people according to the maximum fees they are willing to afford, they indirectly reveal their hidden abilities. Seen from this perspective, in order to obtain the best students it is sufficient to raise fees adequately. Under the maintained assumption that private schools provide better quality education, the empirical counterpart is that we should observe better ability students in private schools, because only for high quality children is rational to pay more for better education. ${ }^{8}$

However, the market allocation mechanism works properly only when financial markets operate perfectly, that is when families can borrow money to afford high fees on the expectation of high ability children. Otherwise, if markets for education financing do not exist, poor parents of high ability children will be outspent by rich parents of lower ability children. Since financial markets for education financing typically either do not exist or are heavily subsidised by the state, meritocratic selection is in general Pareto-superior as an allocative device in class formation. Better students could still be prevented from participating in higher education by high opportunity costs. For this reason, the combination of meritocratic selection and publicly financed scholarships contingent on family income can yield the most efficient matching of student to schools. ${ }^{9}$

But for the sake of discussion, let us assume that we have been able to identify through whatever mechanism the (unobservable) quality of each student. The next problem that arises is how to combine in a class students of different qualities. If learning activity in class is affected by the ability and behaviour of 
classmates, families are not indifferent to the class assignments of their children. Whenever other people's features affect one's current behaviour, we can speak of peer effect to indicate the externality created by each individual on other people. Peer effects can take different forms: conformity, competition, envy, and so on. School classes are a typical example where peer effects reveal themselves. When peer effects matter, a stratified educational system does not necessarily represent the most efficient allocation of students. If the peer effect linearly affects the generation of new human capital (i.e. it enters linearly in the educational production function), then exchanging students between schools does not alter the overall production of human capital. ${ }^{10}$ In contrast, when the educational production function exhibits increasing marginal returns in the peer effect, then perfect segregation is effectively the most efficient allocation of students. On the contrary, whenever we observe decreasing marginal productivity of average ability, then mixing students of different abilities may prove superior in terms of human capital production. ${ }^{11}$

A final aspect related to class formation is the problem of optimal class size. If the educational outcome of a school can be easily identified and priced, then profit maximisation could identify the optimal class size. The real problem, however, is that in order to derive optimal size prescription, it is necessary for the educational production function to be really affected by class size in empirical data, but in this respect the empirical evidence is mixed. ${ }^{12}$

Overall we can summarise this brief review of the problems underlying class formation by saying that in general:

a) we lack a proper device to reveal unobservable components (either students' quality or schools' quality). Market mechanisms based on the availability to pay may reveal Pareto-inferior;

b) we are aware of externalities (peer effects) but we ignore which is the optimal class composition because we do not have sufficient information over the educational production function; as a consequence, we are even unable to estimate an optimal class size for each order of schooling;

c) there even exists no wide consensus in the literature about which are the true determinants of educational attainments of students.

In such a context, it is still possible to speak of cost-effectiveness (either in term of best use of available inputs or in terms of cost-minimising combination of inputs). Even though families react to price signals, however, it is not appropriate to speak of a «market» (or quasi-market) for education, because prices are quite unlikely to convey the correct set of information to both families and policy makers. 


\section{Availability of information}

Another important, but conceptually distinct difficulty in ensuring efficient operation of education systems is the scarcity and poor quality of the relevant information. As we have seen, even if all characteristics of educational production functions were perfectly known, it would be difficult to devise allocation rules and prices. But the individual economic benefits of education accrue much later than the time its costs are paid, are random and hardly verifiable, and depend importantly on behaviour of the student in the labour market as well as on the quality (which is generally difficult to ascertain ex ante) of education. Such information problems generally prevent markets from ensuring that private costs and benefits are fully accounted for by appropriate intertemporal state-contingent contracts and - to the extent that not only the form, but also the extent of social effects is hard to assess - can very well interfere with public allocation mechanisms as well.

Kane and Staiger (2002) offer a review of US experience with school rating, and of theoretical and statistical pitfalls. They report that State educational systems increasingly rely on sanctions, and more frequently bonuses, to motivate schools and teachers. Financial rewards typically can be used for schoolwide expenditures, but in California, North Carolina, and Texas awards directly affect teachers' pay. Good performance is assessed at the school level on the basis of standardized test score increases. It is not surprising, but certainly worrisome, to see that available indicators of pupil achievement are extremely "noisy», and therefore unreliable. School-level effects account for only $15 \%$ of the overall cross-sectional variance of individual test scores, and are very volatile on the yearly scale used to assess performance and award financial resources. Kane and Staiger sensibly doubt that the small impact of individual schools on their students' performance can motivate their teachers and managers to exert additional effort in order to reap financial rewards that are determined to a large extent by luck. Moreover, they list theoretical reasons why awarding financial resources on the basis of observed performance may actually worsen relevant aspects of school performance. Good pupil performance can reflect the source population's background, and rewarding it can channel resources towards richer local constituencies, with dubious effects on the system's equity (and, to the extent that education is a public good, its efficiency as well): relying on test score improvements can partially remove this effect, but only at the cost of introducing additional noisiness. And tests can never assess a child's overall achievement. In practice, only simple reading and math skills are tested, and the testing procedures are imperfect - both because of coding and statistical errors, and because teachers have incentives to coach students about the specific skills tested rather than more general ones, even within the narrow field of 'testable' skills. 13

All this, of course, may diminish, but does not eliminate altogether, the usefulness of testing. Standardized tests are clearly only a proxy of labour marketrelevant skills, but it is common for proxies to play a relevant economic role when 
direct performance measures are not available. Academic careers are based on publications, rather than on direct measures of knowledge, creativity, and dedication, and airline pilots' careers depend on fuel consumption and timeliness rather than on the likelihood of fatal crashes. And standardised test scores appear to be an empirically relevant proxy: Kane and Staiger report other studies' measures of the wage impact of test performance, which appears quite relevant.

Still, it is important to keep in mind that relying on imperfect performance measures has potential drawbacks, dramatically illustrated by recent accounting scandals. At Enron, Worldcom, and similar firms, managers were rewarded on the basis of their ability to beat simple sale or stock-price targets, and had obvious incentives to manipulate the relevant indicators in the absence of perfect monitoring. Similarly, one would not want to design a reward system for teachers that would lead them to target performance measures that are both incomplete and easily manipulated.

\section{The nature of competition among schools}

In previous sections we have listed a series of reasons why it is hard to apply the traditional paradigm of market efficiency to the analysis of education: imperfect knowledge of production technology, imperfect observability of students' quality, imperfect information on schools quality. Nevertheless we read quite often pleas to increase school competition as a useful device to improve schools' efficiency and consequently schools' quality. A typical way to increase competition among otherwise identical education providers is to favour their differentiation.

In section 2 we have already discussed alternative strategies to increase school stratification, along different dimensions (comprehensive vs. stratified curricula, public vs. private schools, centrally financed vs. locally financed institutions). We now review the potential consequences of introducing/expanding competition among schools along one or more of these dimensions.

\section{Generalist vs. stratified}

The choice between generalist vs. stratified schools poses the problem of early tracking. The more stratified is a school system, the more irreversible becomes the choice of school type. Previous school levels are crucial in sorting students. The existence of diversified curricula could strengthen the effect of family background and reduce the degree of social mobility. However this does not seem to be the case empirically. Table 3 reproduces the estimate of the degree of educational mobility across generations, as measured from intergenerational transition matrices computed on the European Household Panel (1994-1997). Countries with strongly diversified curricula (like Germany and the Netherlands) exhibit high degree of educational mobility, suggesting that stratification per se does not contradict the equality of opportunities. 
Table 3: Intergenerational mobility matrices in educational attainment Source: Comi 2003, table 6 and 7.

\begin{tabular}{|l|c|c|c|c|}
\hline \multirow{2}{*}{ Country } & \multicolumn{2}{|c|}{ father-son } & \multicolumn{2}{c|}{ mother-son } \\
\cline { 2 - 5 } & Second eigenvalue & rank & Second eigenvalue & rank \\
\hline Austria & 0.045 & 1 & 0.044 & 3 \\
\hline Netherlands & 0.061 & 2 & 0.000 & 1 \\
\hline United Kingdom & 0.089 & 3 & 0.136 & 7 \\
\hline Germany & 0.095 & 4 & 0.052 & 4 \\
\hline Denmark & 0.114 & 5 & 0.033 & 2 \\
\hline Greece & 0.149 & 6 & 0.118 & 5 \\
\hline Spain & 0.160 & 7 & 0.168 & 9 \\
\hline Belgium & 0.185 & 8 & 0.135 & 6 \\
\hline Italy & 0.210 & 9 & 0.167 & 8 \\
\hline Ireland & 0.276 & 10 & 0.271 & 11 \\
\hline Portugal & 0.296 & 11 & 0.274 & 12 \\
\hline France & 0.298 & 12 & 0.224 & 10 \\
\hline
\end{tabular}

Note: Transition matrices are square, and reports the offspring's probabilities of attaining each education level conditional on the parent's attainment. The second-largest eigenvalue of such matrices is one of the possible measures of intergenerational persistence of educational attainment. The larger is the value of that eigenvalue, the faster is convergence of the distribution of educational achievements towards its long-run configuration, and the less important is the parents' achievement as a determinant of the children's achievement.

Hannan, Raffe and Smyth (1996) have suggested that the crucial dimension in shaping the degree of social mobility is not given by curricula differentiation but by the degree of standardisation within each curriculum. This could explain why Italy, France or Spain emerge as less mobile despite a lower degree of differentiation. At the other extreme of reduced/absent differentiation, we find the United Kingdom, which scores quite high in the mobility league. In addition we should not forget that in general stratified countries have lower educational achievement.

It is clear that a stratified school system, as in any case of product differentiation, implies a low degree of competition, at least between school types. However increasing the degree of comprehensiveness of the school system need not be a very efficient way to foster school competition, because comprehensive schools can remain differentiated along public/private, urban/rural, and other dimensions.

\section{Private vs. public}

A better strategy to increase competition is the creation (or the expansion) of the private sector in school provision. The presence of private schools alongside public ones can have important implications for the scope and character of education. If the cost of private education is borne directly by families, and financial market imperfections generally constrain poorer families' educational investments, then, the customer base of private schools includes only students from families that are relatively rich and, to the extent that educational achievement 
and financial resources are correlated in a market society, are also better educated. As regards the first, social role of schools, this implies that the children of «better» families will only learn to interact with each other, not with their poorer cohorts who remain segregated in cheaper public schools. As regards the other roles, conversely, private incentives to obtain good schooling may lead to efficiency when oriented to labour market success, but may not coincide with political and social goals when oriented to replicate social stratification by emphasizing the scarcity value of elite education.

A related question is whether the private sector provides better quality education. Given the fact that (richer) families are willing to pay a price for schooling that is otherwise free, one is led to infer that there has to be something valuable for families. In the 1980s, the extensive «High School and Beyond» survey offered American economic and social researchers rich opportunities to study the relationship between family background, school curricula, and subsequent labour market success. A particularly controversial, but robust finding was that a Catholic appears to be associated with labour market and further education outcomes that are slightly more favourable on average and, especially, less tightly related to the students' background. ${ }^{14}$ To understand how the relevant effects were estimated, and to interpret them, it is important to note that in the United States Catholic schools are not attended only by Catholic students. Many Catholic schools are located relatively poor urban neighbourhoods, where Irish and Italian immigrants first settled before moving to the suburbs and leaving the inner cities to newer and poorer minorities. So, they are attended by a mix of students with heterogeneous backgrounds, while enrolment in a Catholic school is ceteris paribus more likely for the children of Catholic families. This makes it possible for researchers to try to disentangle the effects of schooling from those of background characteristics, under the identifying assumption that a Catholic background makes Catholic schooling more likely but does not otherwise influence a student's performance in higher education and in the labour market. ${ }^{15}$

Apart from quality considerations, some parents may elect to send their children to private schools because they explicitly support certain values, such as religion (Sanders, 2001); others because private schools have better facilities, such as libraries and laboratories, or lower transportation costs. Sometimes the quality of education or facilities is not even the main issue. Some people consider private education a status symbol (Fershtman, Murphy \& Weiss, 1996), a way of improving their own and their children's social networks, of shielding their children from social problems, avoiding contact with immigrants and children with handicaps, or simply because they do not approve of the open and more heterogeneous public school environment (Gradstein \& Justman, 2001).

Empirically, it is hard to determine which factors drive parents' choices. Some of the variables that might affect parents' choice are not observable (for instance, parents' perception of children's abilities and how they will perform in the labor market) or difficult to measure (for instance, intensity of religious belief). Oth- 
ers are easier to measure, at least in principle. In particular, the quality of education should be the main factor if parents consider private education as an investment good. If instead parents base their decisions on other characteristics, quality should not be a major concern.

Checchi and Jappelli (2002) study the educational choice of Italian families with respect to accessing private schools. They find that the quality of public schools (as subjectively perceived by parents or as measured by provincial indicators of school resources) is an important determinant of the choice between private and public schools, even controlling for provincial fixed effects. They also find that private school attendance at the compulsory level is strongly correlated with parents' income, while larger family size and, in elementary and lower secondary schools, the presence of a housewife reduce the probability of private enrolment. If we measure school quality from the impact exerted onto subsequent school performance, the evidence on quality is mixed. Using the university records of a sample of Italian students, Bertola and Checchi (2001) find that private school attendance does not necessarily imply an improvement in educational careers. Their explanation of this evidence is based on the peculiar selfsorting mechanisms operating in Italy, where students with heterogeneous talent and family background characteristics can choose among a wide menu of coexistent and overlapping generalist/vocational, public/private, and lay/confessional schooling options. On average, academic performance is better among students from public schools. However, private schools (both confessional and lay) improve performance of a subgroup of students whose choice of private school attendance is correlated with family wealth.

Summing up, given the mixed evidence on private school quality, and taking into account that private school choice is governed by «amenity» considerations (confessional orientation, status symbol, equipment, and so on), favouring the expansion of the private sector will definitely improve families' welfare (because the enlarged feasible set of choice), but does not necessarily imply improved competition among schools. Yet beneficial effects on school quality may come from increased competition from private onto public schools (but this does not necessarily require a private system, though a more decentralised financing - see below). When customers pay for services, they are presumably more motivated to monitor the quality of education received. Hence, competition among schools (whether private, or publicly funded on the basis of enrolment) can increase efficiency of education supply.

\section{Central vs. Local financing}

The centrally financed vs. locally financed dimension contains two aspects. Centralisation can regard the organisation (teachers selection, educational contents) or may refer to the financing aspect only. A centrally organised system provides scarce incentives to performance and is typically exposed to teachers' union pressures; ${ }^{16}$ nevertheless it ensures homogeneity independently of wealth distribu- 
tion in the population. In a centralised system (where educational contents are homogeneous across the country, teachers are selected on a national basis, class standards are identical) the educational degrees have typically a nation-wide recognition, thus increasing social equality: students from low-income families (which can reflect a low level of acquired human capital) should have access to the same level of education as those from a higher income family. ${ }^{17}$

The second aspect concerns financing. A decentralised system creates stronger incentives to make more efficient use of resources in order to attract more students (if the local financing is on a per-student basis) and because of stronger parental control. Fiske and Ladd (2000) review the large-scale school reform undertaken in New Zealand between 1989 (labour government) and 1991 (nationalist government). The state system of compulsory education was fully decentralised; administrative responsibility was passed to locally elected boards of trustees; charter schools (combining central funding and accountability with autonomy of management) were also introduced. Oversubscribed schools had the right to designate criteria of admission (thus shifting the system from «increased parental choice» to «increased school choice»). According to the evidence collected by the authors, better-educated parents mainly exploited the increased availability of choice. Five years after the reform, they noticed an increased polarisation of enrolment by ethnic and/or socio-economic groups. They also report an increased polarisation among schools: the most popular schools attracted most of the students oriented to a university career, better teachers and wealthier families. A still unsolved question had to do with low performing schools, typically located in culturally (and economically) deprived areas. The reform left this issue unsolved, leading the authors to suggest that the new mechanism did not provide any formal mechanism for balancing the narrow interests of a particular group of parents against the legitimate needs of broader communities: "The bottom line is that it is impossible to sustain a system in which all parents are completely free to select the school their child will attend. Some mechanism must be devised for rationing places in popular schools, and this inevitably involves constraints on choice. The challenge is to keep the constraints from falling disproportionately on students from disadvantaged families...». 18

The increased variety of experiences allowed for by local financing makes it more difficult to assess students level and may pose problems in the sequence of educational levels. While a nation-wide certification cannot survive such a process of decentralisation, a unified framework is still required, and student competences have to be assessed by uniform test scores (as in the case of SAT scores for admission to US universities).

All things considered, decentralisation of funding may be the best strategy to increase school competition without excessive reliance on families' wealth (as when expanding the private sector) and without radical reform of the structure of the educational system (with respect to alternative tracks). 


\section{Modes of choice and modes of financing}

Different market failures are differently relevant for different types of education. Public-good aspects are most relevant for primary education, whose main purpose is the formation of minimal social skills. At higher levels of education, schooling offers private benefits, in the form of specialized skills and selective certification, but also in the form of exclusive status. Hence, one may expect a decentralized system of private or locally funded schools to foster efficiency. Not only an explicitly private school market, but also a locally funded system (as long as families can and do relocate across school-district lines) or a system where school funding depends on enrolment figures can all let families choose the school attended by their children, control the quality of the education they receive, allocate more resources to better-functioning schools, and provide appropriate incentives to (or induce exit of) less efficient providers.

The extent to which enrolment can influence the efficiency of school systems and improve pupil achievement is, of course, not perfect. Hirschman (1970, p. 1617) chose the possibility of school quality control through enrolment mechanisms, advocated by Friedman (1955) as a suitable mechanism, as an example of the scarce effectiveness of economic "exit» mechanisms in situations with complex, heterogeneous, and uncertain payoffs and interactions. Socio-political "voice» channels are certainly very active in all schools, whether private or public, to the extent that different families care differently about different aspects of their children's educational experience. Still, the US evidence indicates that differential schooling expenditure does play a role in determining private returns ${ }^{19}$ and, by extension, that the relevant «exit» mechanisms are at work in that country fostering private efficiency (if not necessarily social objectives).

However in our opinion the risks associated to an excess of «voice» to families in the case of school choice are relevant. We have already argued above that market failures are more likely when information is imperfect, and that the evidence of private school quality is blurred by other characteristics (mainly self-selection of students). Before advocating financial influence of individual-level choices it is important to consider that the quality of education is not as easy to assess as that of groceries. Educational inputs (such as the number and qualifications of teachers, and the size and quality of classrooms) are to some extent observable and measurable, but educational output depends importantly on the quality of the student pool attracted. In principle, the quality of an educational experience should be evaluated on the basis of the students' labour market experience in the decades after graduation. In practice, the perceived quality of education is strongly influenced by a school's reputation (which changes very slowly, and effectively prevents new entrants from contesting the incumbents' market position) and by a variety of possibly spurious indicators, such as the pleasantness of the school's premises.

Thus, while the social benefits of widening the menu of available choices are 
unclear, the socialising role of education is unambiguously weakened by the expansion of the private sector. At least at compulsory level, where social externalities are presumably higher, private schools limit to the ability of the educational system to provide all future citizens with a full spectrum of relational abilities. Targeted school vouchers can nullify the private/public divide, but it still remains true that under imperfect financial markets poorer families cannot finance long curricula. And even under student aid (compensating for income differences once a student is enrolled), poorer families may be more risk adverse (if the coefficient of risk aversion is a function of family income). The idea of a graduate tax could represent a partial solution: students pay a large part of their investment only if successful (i.e. after finding a job paying a positive premium over non graduate workers) ${ }^{20}$

The alternative strategy is decentralisation, both in funding and in curricula, while retaining the public source of funding. An increased variety of alternatives raises competition among schools to attract students, and may be beneficial to school quality (at least in terms of more effective use of available resources). However a decentralised educational system is ineffectual in yielding these improvements whenever territorial mobility costs are insurmountable. While in the cases of the UK and the US there is evidence of territorial mobility related to local school quality, similar evidence is absent with respect to most European countries. Even if the efficiency gains do not materialise, there are still good reasons to allow for decentralisation in order to increase families' freedom of choosing according to their priorities in the education of the offspring.

The most likely consequence of increased variety is the strengthening of neighbourhood effects, because it increases the homogeneity of cultural milieu within each school. In a decentralised setting, schools are induced to specialise in producing a differentiated commodity, and the market for education becomes segmented. Whether this increases or reduces the average educational achievement depends on the underlying educational production function. ${ }^{21}$ The main problem that we see in this respect is the different degree of information across families. Parents value education in different ways, presumably in relation with their own educational experience. Parents who experienced failures at school will consider education as a risky investment, and are more likely to choose easy schools for their children. ${ }^{22}$ At the opposite extreme, educated parents, who experienced the market value of education, will push their offspring in order to follow their footprints. Thus increased freedom of choice may result in a selection of talents that is inefficient from a social point of view. 23

We believe that even in this respect expected costs in terms of inequality may exceed the benefits in terms of enlarged opportunities. Our viewpoint is that there is a body of knowledge that society wants the student to learn, and from this perspective a school system must be centrally organised and publicly financed. However, excessive uniformity dampens the incentives to emerge. Arguably, these incentives should derive from meritocratic stratification of the ed- 
ucational system, where talent, and not wealth, buys access to better schools. The creation of excellence schools does not reduce either educational or income inequality, but has the undeniable advantage of providing an equality of opportunities starting base for anyone.

\section{Concluding remarks}

As anticipated in the introduction, the case for private or public achievementaware financing is easily made on the basis of obvious incentive mechanisms. But it is almost as easily criticised on the basis of sometimes less obvious, but pervasive, market failures in the education field. Differentiating school financing unavoidably tends to introduce differentiation in schooling, which may have adverse implications when externalities would call for a degree of uniformity in school curricula. And allowing resource allocation to depend on observable outcomes may similarly damage efficiency if the more relevant pieces of information are not easily observable by the (private or public) agents in charge of financing.

In summary, financial incentive considerations should not be excluded from either public or private schooling systems. However, the simplicity and transparency of the overall funding system have important virtues in this field. Excessive reliance on unavoidably imperfect performance-related funding systems can backfire, to an extent depending on the observability and private character of educational outcomes.

\section{Notes}

1 See for example the surveys contained in Hanushek, 1996, 2002. Prichett and Filmer 1999 argue that the absence of statistical effect of school resources in estimating educational production functions can be attributed the «saturation effects» (i.e. these resources are used up to the point where the marginal productivity is nil). Carneiro and Heckman 2003 question the idea that family financial resources may prevent school attendance.

2 «In school systems with differentiated school types, the clustering of students with particular socio-economic characteristics in certain schools is greater than in systems where the curriculum does not vary significantly between schools. In Austria, Belgium, the Czech Republic, Germany, Italy and the Netherlands, for example, the between-school variation associated with the fact that students attend different types of school is considerably compounded by differences in social and family backgrounds» (OECD, 2003, p.82).

3 See Hoxby 1997, where she shows that American universities have incentives to segment the market for tertiary education, in order to attract the best students, who in turn are the best input for educational production.

4 See the discussion of this issue in Blöndal, Field and Girouard (2002).

5 «A stable and democratic society is impossible without a minimum degree of literacy and knowledge on the part of most citizens and without widespread acceptance of some common set of values. Education can contribute to both. In consequence, the gain from the education of a child accrues not only to the child to his parents but also to other members of society» (Friedman, 1955, p. 86.) 
6 Bertola and Coen Pirani 1998 propose a model where schooling is described as a screening activity (they term it «allocative education»), the precision of which depends on the amount of invested resources.

7 In addition, the incentive to undergo an exam declines when students do not have an informational advantage on their own ability. Stiglitz 1975 discusses this case, in the context of a general theory of screening.

8 Fernandez 1998 studies the case of allocating students of different abilities across schools of different quality. She shows that under perfect capital markets two allocative mechanisms (admission fees and test scores) yield efficient outcomes (in terms of human capital production). Under borrowing constraints, exams dominate market mechanism in terms of matching efficiency (allocating better students to better schools).

9 Fernandez and Gali 1999 propose a model where meritocratic selection (in relative terms, like a tournament) reach matching efficiency, associating better students to better schools in absence of financial markets. Here the crucial assumption relates to the assumed negative correlation between unobservable ability and the cost of signalling, thus allowing to the best students to emerge irrespective of their social origin.

10 This is straightforward, because exchanging a good student for a bad student reduces the average ability in the good-type school and raises the average ability in the bad-type school. Given an identical educational production function, the reduced production of human capital in good schools is matched exactly by the increase in bad schools. (See Hoxby, 2000.)

11 Continuing the example introduced in the previous footnote, when we exchange students between high-ability schools and low-ability schools under decreasing marginal productivity of the average ability (peer effect) the human capital loss in the first type of schools is overcompensated by the gain in the second type of schools.

12 Krueger 1999 analyses the available evidence on the STAR (Student/Teacher Achievement Ratio) experiment run in Tennessee in the period 1985-89, where 11.600 students in their first four years of school were randomly assigned to classes of different sizes. He finds that after controlling for observable characteristics of the student and his/her family background, «in all grades, the average student in small classes performed better on this summary [the achieved percentile in the distribution of test scores] than did those in regular and regular/aide classes». Instead of reviewing a randomised experiment, Woessman and West 2002 analyse a larger sample from the TIMSS (Third International Mathematics and Science Study) conducted during the academic year 1994-95 by IEA (International Association for the Evaluation of Educational Achievement) across 40 countries. They find evidence of a negative effect of class size on 13-year old students in 4 cases out of 36 cases, leading to the conclusion that «in the vast majority of cases, however, the estimated coefficient is not statistically significantly different from zero".

13 Kane and Staiger report an arresting example whereby the format - horizontal rather than vertical - of math exercises was enough to alter test scores dramatically, and the students' subtraction skills were markedly lower than the addition skills they expected to be tested on.

14 See e.g. Altonji, Elder and Taber, 2000; Coleman, Hoffer, and Kilgore, 1982; Evans and Schwab, 1995; Neal, 1997.

15 In the United States, public education is locally funded, hence its quality is far from uniform, and it is not surprising to find that private schools offer better education. It is harder however to understand why attendance of Catholic schools should not only benefit American students on average (in terms of better opportunities for and better performance in higher education, and labour market outcomes), but also be especially beneficial for students from disadvantaged backgrounds. It has been suggested that a student culture based on self-discipline, on the notion that "No one fails who works hard," and on the feeling of 
belonging to a voluntary community may be an important asset for primary and secondary Catholic educational establishments. There is also some evidence that the teachers employed by Catholic schools are better monitored and more highly motivated than their colleagues who work - for significantly higher wages - in public schools (see Bryk et al. 1993 for a recent review of this literature)

16 Hoxby 1996 finds that unionisation of teachers can account for greater use of educational inputs; this evidence is consistent with either teachers having better information about educational production function (efficiency-enhancing) or with teachers' unions being rent seekers. In addition to educational budget expansion, teachers' unions may also be able to change budget allocation in favour of inputs that reduce teachers' effort (like reducing class size and/or teaching load per teacher) or increase teachers' salaries.

17 Checchi, Ichino and Rustichini 1999 compare the centralised nature of the Italian educational system with the largely decentralised nature of the US system, under the theoretical expectation of a more compressed distribution of human capital investments (and therefore of incomes) matched by a higher likelihood of upward mobility for poor families in the more centralised country. They find evidence of the former but not of the latter proposition.

18 Fiske and Ladd 2000, p.287.

19 As reflected e.g. by housing values; see Barrow \& Rouse, 2002.

20 «A governmental body could offer to finance or help finance the training of any individual who could meet minimum quality standards. [...] The individual in return would agree to pay to the government in any future year a specified percentage of his earnings in excess of a specified sum for each $\$ 1000$ that he received from the government. [...] The base sum should be set equal to the estimated average earnings without the specialized training; the fraction of earnings paid should be calculated so as to make the whole project self-financing. [...] the free choice of individuals would tend to produce the optimum amount of investment.» (Friedman 1955, p. 106.) See the empirical application of similar ideas in Australia, as reported by Chapman, 1997.

21 Whether student abilities are complements or substitutes in the educational production function, (see Benabou 1996).

22 Piketty 1995 presents a similar model where the attitude towards fiscal redistribution depends on past experience of social mobility: individuals who experienced low mobility vote for more redistribution, whereas individuals with an experience of higher mobility will expect it to last in the future and will oppose redistribution on the expectation of becoming richer.

23 There is a wide debate on what can be defined as social efficiency. See for example the following quote by Pareto:

Dans les sociétés modernes, les éléments de la stabilité sont donnés par la propriété privée et l'hérédité; les éléments de la mutabilité et de la sélection viennent de la faculté donnée à tous de monter autant que faire se peut dans la hiérarchie sociale... Si on pouvait d'une façon efficace supprimer quelque espèce de propriété privée, par exemple celle des capitaux, et, en partie ou en totalité, l'hérédité, on affaiblirait beaucoup l'élément de stabilité, et on renforcerait l'élément de mutabilité et de sélection. On ne peut pas décider a priori si cela serait utile ou nuisible à la société. (Pareto, 1966, p. 426-427).

From a different ideological perspective, Marx was well aware of the same concept of social stability: "Although the circumstances continually bring an unwelcome number of new soldiers of fortune into the field and into competition with the already existing individual capitalists, it also reinforces the supremacy of capital itself, expands its base, and enables it to recruit ever new forces for itself out of the substratum of society ... The more a ruling class is able to assimilate the foremost minds of a ruled-class, the more stable and dangerous becomes its rule» (Marx, Capital, vol. III - quoted in Goldthorpe, 1980, p. 5). 


\section{References}

Altonji, J., Elder, J. \& Taber, C. (2000). Selection on observed and unobserved variables: assessing the effectiveness of catholic schools. National Bureau of Economic Research working paper n.7831.

Barrow, L., \& Rouse, C. (2002). Using Market Vauation to Assess Public School Spending. National Bureau of Economic Research working paper n. 9054.

Benabou, R. (1996). Heterogeneity, stratification and growth: Macroeconomic implications of the community structure and school finance. American Economic Review, 86, (3), 584609.

Bertola, G. \& Checchi, D. (2001). Sorting and private education in Italy. Lavoro e Relazioni Industriali, 2, 87-124.

Bertola, G. \& Coen Pirani, D. (1998). Market failures, education and macroeconomics. In G. Barba Navaretti, P.Dasgupta, K.-G. Mäler \& D. Siniscalco (Eds.), Creation and Transfer of Knowledge: Institutions and Incentives (p. 179-207), Berlin: Springer.

Blöndal, S., Field, S. \&Girouard, N. (2002). Investment in human capital through post-compulsory education and training. OECD Economic Department Working Paper n. 333. Paris: OECD.

Bryk, A.S., Lee, V.E. \& Holland, P.B. (1993). Catholic schools and the common good. Cambridge: Harvard University Press.

Carneiro, P. \& Heckman, J. (2003). Human capital policy. National Bureau of Economic Research working paper n.9495.

Chapman, B. (1997). Conceptual issues and the Australian experience with income contingent charges for higher education. Economic Journal, 107, 738-751.

Checchi, D. \& Jappelli, T. (2002). School choice and quality. Working paper 28.2002. Dipartimento di Economia Politica e Aziendale, Università di Milano.

Checchi, D., Ichino, A. \&Rustichini, A. (1999). More equal but less mobile? Intergenerational mobility and inequality in Italy and in the US. Journal of Public Economics, 74, 351393.

Coleman, J.S., Hoffer, T. \& Kilgore, S. (1982). High school achievement: public, catholic, and private schools compared. New York: Basic Books Inc.

Comi, S. (2003). Intergenerational mobility in Europe: evidence from the ECHP. [s.l.: mimeo].

Evans, W.N. \& Schwab, W.M. (1995). Finishing high school and starting college: Do catholic schools make a difference? Quarterly Journal of Economics, 110, (4), 941-74.

Fernandez, R. (1998). Education and borrowing constraints: test vs. prices. CEPR discussion paper n. 1913

Fernandez, R. \& Gali, J. (1999). To each according to ... ? Markets, tournaments and the matching problem with borrowing constraints. Review of Economic Studies, 66, 799-824.

Fershtman, C., Murphy, K. \& Weiss, Y. (1996). Social status, education, and growth. Journal of Political Economy, 104, 108-32.

Fiske, E. \& Ladd, H. (2000). When school compete - a cautionary tale. Washington DC: Brookings Institution Press.

Friedman, M. (1955/1962). The role of government in education. In Capitalism and freedom (p. 85-107). Chicago: University of Chicago Press.

Goldthorpe, J. (1980). Social mobility \& class structure in modern Britain. Oxford: Claredon Press.

Gradstein, M. \& Justman, M. (2001). Public education and the melting pot. Center for Economic Policy Research. Discussion Paper n. 2924.

Hannan, F., Raffe, K. \& Smyth, J. (1996). Cross-national research in school to work transition: an analytical framework. Paris: OECD [mimeo].

Hanushek, E. (1996). Measuring investment in education. Journal of Economic Perspectives, 10, (4), 9-30. 
Hanushek, E. (2002). Publicly provided education. National Bureau of Economic Research working paper n. 8799 (forthcoming in A. Auerbach \& M. Feldstein (Eds.), Handbook of public economics. NorthHolland.).

Hirschman, A.O. (1970). Exit, voice, and loyalty. Cambridge \& London: Harvard University Press.

Hoxby, C. (1996). How teachers' unions affect education production. The Quarterly Journal of Economics, 111, (3), 670-716.

Hoxby, C. (1997). How the changing market structure of US higher education explains college tuititon. National Bureau of Economic Research working paper n. 6323.

Hoxby, C. (2000). Peer effect in the classroom: learning from gender and race variation. National Bureau of Economic Research working paper n. 7867.

Kane, T.J. Staiger, D.O. (2002). The promise and pitfalls of using imprecise school accountability measures. Journal of Economic Perspectives, 16, (4), 91-114.

Krueger, A. (1999). Experimental estimates of education production functions. Quarterly Journal of Economics, 114, (2), 497-532.

Lazear, E. (2001). Educational production. Quarterly Journal of Economics, 116, (3), 777-803.

OECD (2003). Education at a glance. Paris: OECD

Pareto, V. (1909/1966). Manuel d'economie politique. Genève: Droz.

Piketty, T. (1995). Social mobility and redistributive politics. Quarterly Journal of Economics, 110, (3), 551-584.

Pritchett, L. \& Filmer, D. (1999). What educational production functions really show - A positive theory of educational spending. Economics of Education Review, 18, 223-239.

Sander, W. (2001). The effect of Catholic schools on religiosity, education and competition. National Center for the Study of Privatization in Education Occasional Paper n. 32 ( $h t t p: / / w w w . t c . c o l u m b i a . e d u / n c s p e)$.

Stiglitz, J. (1975). The theory of «screening», education and the distribution of income. American Economic Review, 64, (3), 283-300.

Tiebout, C. (1956). A pure theory of local expenditure. Journal of Political Economy, 64, 416424.

Wössman, L. \& West, M. (2002). Class size effects in school systems around the world: evidence from between-grade variations in TIMSS. Institute for the Study of Labor discussion paper n. 485 


\section{Bildungsfinanzierung und Ausbildungserfolg}

\section{Zusammenfassung}

Der vorliegende Beitrag gibt zunächst einen kurzen Überblick darüber, wie sich finanzielle Ressourcen auf die Menge, die Qualität und die Heterogenität von Bildungsangeboten auswirken und dadurch den Ausbildungserfolg beeinflussen. Anschliessend werden die Effekte unterschiedlicher Möglichkeiten, mit dem Einsatz finanzieller Ressourcen den Ausbildungserfolg zu beinflussen, diskutiert. Speziell wird der Unterschied zwischen familienbasierter und staatlicher finanzieller Unterstützung fokussiert.

\section{Financement de l'éducation et réussite des élèves}

\section{Résumé}

Dans cet article, nous passons brièvement en revue les modalités selon lesquelles les ressources financières des écoles affectent la quantité, la qualité et l'hétérogénéité de l'offre éducative. Nous examinons ensuite l'influence de celle-ci sur les résultats des élèves. Enfin, nous discutons des effets exercés par les différentes manières de mettre en relation les ressources des écoles sur les résultats des élèves, en nous intéressant particulièrement à la distinction entre le financement par la famille et le financement par l'État.

\section{Finanziamento dell'educazione e risultati degli studenti}

\section{Riassunto}

In questo lavoro offriamo una breve rassegna di come le risorse finanziarie influenzino la quantità, qualità, ed eterogeneità dei servizi educativi scolastici, e di come tali servizi a loro volta influenzino i risultati ottenuti dagli studenti. Procediamo quindi a discutere vari possibili meccanismi di collegamento tra risorse scolastiche e risultati educativi, studiando in particolare le differenze tra canali di finanziamento basati su decisioni familiari e su scelte collettive. 
T $h$ e $\mathrm{m} \mathrm{a}$ 